ISSN: $2036-5438$

\title{
The German Bundesrat and Executive Federalism
}

by

\author{
Matthias Niedobitek*
}

Perspectives on Federalism, Vol. 10, issue 2, 2018 


\section{Abstract}

The German Basic Law constitutes federalism as a unique political system which is characterised by intertwined decision-making of the Federation (Bund) and the component units (Länder). The executives of the two federal tiers and the Länder executives within the Bundesrat play a major role in making joint decisions. They are forced to make decisions in the 'joint-decision mode' (Politikverflechtung) which is detrimental to accountability. Reform efforts were made to unbundle competences and to reduce the number of bills which require the Bundesrat's consent. Due to the dominance of the executives and the distribution of powers between the federal tiers (legislation is dominated by the Bund, execution is dominated by the Länder), German federalism is rightly called 'executive federalism'. German federalism can even be regarded as an embodiment of that concept since it covers all possible aspects of 'executive federalism'. The Bundesrat has an important share in that classification.

\section{Key-words}

executive federalism, second chamber, German parliament, distribution of legislative powers, asymmetric federalism 


\section{Introduction. The main characteristics of German federalism}

The Basic Law establishes Germany as a federal state (Bundestaat, cf. Article 20 para. 1 $\mathrm{BL}$ ). As a federal state, Germany consists of two federal tiers, both of which have state character: The Federation and the individual Länder. The statehood of the German Länder is reflected in many provisions in the Basic Law as well as in the fact that all the Länder have adopted their own written constitutions.

Besides the two federal tiers there is no third federal tier representing the entirety of Bund and Länder, a so-called 'entire state' (Gesamtstaat). Rather, the Bund combines two qualities: (a) internally, in its relationship to the Länder, it is a 'central state'; (b) externally, in its relationship to third countries, international organisations etc. it is the 'entire state', now including the Länder (cf. Niedobitek 2001: 52 et seq.)

Without doubt, the Länder are subordinate to the Bund insofar as the Basic Law provides for a hierarchical order between the Bund and the Länder (cf. BVerfGE ${ }^{\mathrm{I}}$ 13, 54/78 et seq.). To mention only a few examples: (a) Pursuant to Article 31 BL federal law shall take precedence over Land law; (b) Article 72 para $1 \mathrm{BL}$ stipulates that on matters within the concurrent legislative power, the Länder shall have power to legislate only so long as and to the extent that the Federation has not exercised its legislative power by enacting a law; (c) international treaties of the Länder require the consent of the Federal Government pursuant to Article 32 para 3 BL; (d) territorial reform of the Länder can be enacted by a federal law pursuant Article 29 para 2 BL.

But apart from this, the Bund and the Länder are on an equal footing as the Federal Constitutional Court has constantly held (cf. Niedobitek 2013, no. 43, 73). Accordingly, the Court has confirmed that that the Länder are not derived from the Federation but are rather recognised by it (BVerfGE 60, 175/207).

As a rule, the exercise of state powers and the discharge of state functions are matters for the Länder (Article 30 Basic Law). However, as a result of the constitutional distribution of competences between the Bund and the Länder, the Bund is dominant in the field of legislation while the Länder's domain is execution of federal laws (alongside Land laws). This division of responsibilities is, however, not as clear as it may seem at first glance. Rather, 'it is a system of cooperation, interconnections, and interrelationships' (Gunlicks 
2003: 61): On the one hand, the Länder take part in federal legislation via the Bundesrat, on the other hand, when carrying out federal laws the Länder'may be subject to many federal instructions and restrictions which they can usually influence via the Bundesrat (Gunlicks 2003: 61; cf. Articles 84, 85 BL).

The unique features of the German federal system have created a particular mode of decision-making which Fritz W. Scharpf and others have called Politikverflechtung (JointDecision Mode). The Joint-Decision Mode applies to bills that require the Bundesrat's consent (Benz, Detemple and Heinz 2013: 155). This mode, which cannot be dealt with in detail here (cf. the contribution of Benz in this volume), is a particular form of coordination between the Bund and the Länder which compels the legislative actors to perform their shared competences jointly (Benz 2015: 196 et seq.). It is argued that performing public tasks in the Joint-Decision Mode results in inefficient decisions (although according to Sturm 2009, p. 147, this is not proven). Therefore, the unbundling of legislative competences between the Bund and the Länder and between the Bundestag and the Bundesrat has become a constant issue on the German federalism reform agenda (Benz, Detemple and Heinz 2013: 155 et seq.).

Questions of symmetry in German federalism continue to be raised. Generally speaking, it is clear that all federal systems comprise more or less elements of symmetry and asymmetry (Burgess 2008: 105). But from a de-jure standpoint the German federal system must be classified as a symmetric system since all German Länder have basically the same legal status under the Basic Law (Sturm 2008: 31 f.). It goes without saying that modifications such as differences of votes in the Bundesrat (cf. below, 3.) are implied. If one, however, considers other elements of the German federal system such as the role of the Bundesrat it clearly has asymmetrical tendencies (Sturm and Winkelmann 2014: 61).

This article concentrates on the German Bundesrat as a unique manifestation of German federalism. It aims at a description of the Bundesrat's present constitutional design with a view to allowing a comparison with other bicameral systems. It first points to the legislative function of the Bundesrat and its political clout (2.). Next, it outlines the Bundesrat's characteristic features (3.) which make it a qualified form of 'territorial representation'. This, subsequently, enables us to qualify the Bundesrat as the second chamber of the German parliament and, thus, to classify German federalism as a bicameral system (4.). Furthermore, it is possible to localise the Bundesrat within the multifaceted concept of 
'executive federalism' which among other concepts characterises German federalism particularly accurately (5.). The Bundesrat's constitutional design as outlined in the previous sections is not unchallenged. Reform efforts are, however, improbable (6.). The main findings are summarised in the concluding section (7.).

\section{The two legislative bodies of the German federation}

The German constitution, the Grundgesetz (Basic Law $=\mathrm{BL}$ ), provides for two 'legislative bodies' (cf. Articles 55, 59 para. 2, 122 para. $1 \mathrm{BL}$ ): the Bundestag and the Bundesrat. While the Bundestag is the main legislative body whose primary task is to adopt bills (Article 77 para. $1 \mathrm{BL}$ ), the Bundesrat's task as a legislative body is either to give or to refuse its consent or - depending on the constitutional arrangement - to object to the bill in question if necessary (Article 77 paras 2-4 BL). Thus, bills are not jointly adopted by the Bundestag and the Bundesrat but by the Bundestag alone with, however, different forms of participation of the Bundesrat (cf. Article $78 \mathrm{BL}$ ).

Depending on the constitutionally stipulated form of participation of the Bundesrat in the law-making procedure - either a necessity for consent or the possibility to object to a bill - the political composition of the Bundesrat may become important. In the early years of the German constitution, the Bundesrat was considered 'unpolitical': a bureaucratic institution without strong political power. But this changed in the early 1970s; from that time on, the Bundesrat emerged as a 'politicised' institution, a (potential) opponent to the federal government (Oeter 1998: 322 et seq.).

However, compared to the Bundestag, the Bundesrat is still an institution that is dominated by administrative expertise rather than by political debate (Sturm 2009: 147). The reason for this is the composition of the Bundesrat, which consists of members of the Land governments, which are not necessarily - and are often not - composed in the same way as the federal government or the majority in the Bundestag. Rather, depending on the outcome of the Land elections, the Bundesrat may form a forum for the federal opposition (Oeter 1998: 322 et seq.). Irrespective of its composition, the Bundesrat is a federal institution (Risse 2005: 11) and as such not only dedicated to the Länder's interests but also to the interests of the Federation. 
Federal elections last took place on September 24, 2017. After lengthy negotiations among several parties, a new 'grand' coalition was formed on March 14, 2018, consisting of the CDU, the CSU and the SPD. ${ }^{\text {II }}$

Elections within the Länder do not take place at the same time as the federal elections; this follows, inter alia, from the fact that the legislative period in the Länder lasts five years (except Bremen) while federal elections take place every four years. The coming Land elections are scheduled as follows: Bavaria: 14 October 2018; Hesse: 28 October 2018; Bremen: Spring 2019; Saxony: Autumn 2019; Thuringia: Autumn 2019; Brandenburg: Autumn 2019; Hamburg: Spring 2020. ${ }^{\text {III }}$ Each election can change the composition of the Bundesrat and, thus, its general political attitude towards the federal governments' politics.

Today (April 30, 2018), the composition of the German Land governments and the number of votes in the Bundesrat (in brackets) are as follows:

\begin{tabular}{|c|c|c|c|}
\hline $\begin{array}{l}\text { Baden-Württemberg } \\
\text { (6) }\end{array}$ & Grüne / CDU & $\begin{array}{l}\text { Lower Saxony } \\
\text { (6) }\end{array}$ & SPD / CDU \\
\hline $\begin{array}{l}\text { Bavaria } \\
\text { (6) }\end{array}$ & $\mathrm{CSU}$ & $\begin{array}{l}\text { North Rhine- } \\
\text { Westphalia } \\
\text { (6) }\end{array}$ & CDU / FDP \\
\hline $\begin{array}{l}\text { Berlin } \\
\text { (4) }\end{array}$ & SPD / LINKE / Grüne & $\begin{array}{l}\text { Rhineland-Palatinate } \\
\text { (4) }\end{array}$ & SPD / FDP / Grüne \\
\hline $\begin{array}{l}\text { Brandenburg } \\
\text { (4) }\end{array}$ & SPD / LINKE & $\begin{array}{l}\text { Saarland } \\
\text { (3) }\end{array}$ & CDU / SPD \\
\hline $\begin{array}{l}\text { Bremen } \\
\text { (3) }\end{array}$ & SPD / Grüne & $\begin{array}{l}\text { Saxony } \\
\text { (4) }\end{array}$ & CDU / SPD \\
\hline $\begin{array}{l}\text { Hamburg } \\
\text { (3) }\end{array}$ & SPD / Grüne & $\begin{array}{l}\text { Saxony-Anhalt } \\
\text { (4) }\end{array}$ & CDU / SPD / Grüne \\
\hline $\begin{array}{l}\text { Hesse } \\
(5)\end{array}$ & CDU / Grüne & $\begin{array}{l}\text { Schleswig-Holstein } \\
\text { (4) }\end{array}$ & CDU / Grüne / FDP \\
\hline $\begin{array}{l}\text { Mecklenburg } \\
\text { Western-Pomerania } \\
\text { (3) }\end{array}$ & SPD / CDU & $\begin{array}{l}\text { Thuringia } \\
\text { (4) }\end{array}$ & LINKE / SPD / Grüne \\
\hline $\begin{array}{l}\text { Source: Own } \\
\text { https://www.bundesrat.d }\end{array}$ & table on the & basis of the & $\begin{array}{l}\text { Bundesrat's website: } \\
\text {. }\end{array}$ \\
\hline
\end{tabular}

The above table shows that at least six Land governments are likely to support the federal government's legislative proposals in the Bundesrat given that their composition by and large conforms with the composition of the federal government (Bundesrat-votes in brackets): Bavaria (6), Mecklenburg Western-Pomerania (3), Lower Saxony (6), Saarland 
(3), Saxony (4), maybe also Saxony-Anhalt (4). The number of votes in favour of the federal government would be 26 , which is not a majority $(=35)$. However, the member parties of the new 'grand' coalition also participate individually in other Land governments. Thus, currently a clear 'blocking potential' cannot be deduced from the above table.

The 'politicisation' of the Bundesrat and the - prior and continuing - increase in the number of bills requiring the Bundesrat's consent has raised concerns. Depending on its political composition the Bundesrat was ascribed the putative power to block the legislative activities of the Bundestag, or the Federation as such, and to cause legislative gridlock. Even though no empirical verification has been provided for this assumption (cf. Schöbener 2010, Article 50 BL mn. 129; Eith and Siewert 2010: 116; Sturm 2009: 145), the Bundesrat's potential for blockade was seen as problematic. Therefore, reform efforts were made to reduce that potential. Those efforts will be dealt with below (6.).

\section{The German Bundesrat as a federal constitutional body representing the German 'regions'}

\subsection{The Bundesrat's functions}

From the perspective of European Union law the German Länder are 'regions' (Blanke 2016, Artikel 300 AEUV mn. 92) albeit with legislative competences. The Bundesrat primarily serves to represent the interests of the Länder on the federal scene. The Länder are territorial (and political) sub-units of the Federation and their representation must thus be classified as 'territorial' (cf. Sturm 2009, p. 148). In that perspective, the distinction between 'federal' and 'territorial' representation (cf. Groß 2003: 36, Kotzur 2006: 272) is not relevant. The concepts of 'federal' or 'territorial' representation are not categorically different; rather, 'federal' representation must be regarded as a qualified form of 'territorial' representation.

More generally, the Bundesrat is also regarded as an element of vertical separation of powers between the Bund and the Länder (Robbers 2018, Artikel 50 GG mn. 11). Others stress the relationship between the Bundesrat and the Bundestag as federal organs and consider the Bundesrat as an element of horizontal separation of powers (Leunig 2009b: 15). 


\subsection{The Bundesrat's tasks}

The German 'regions' are represented in, and by, the Bundesrat. Article 50 BL says: 'The Länder shall participate through the Bundesrat in the legislation and administration of the Federation and in matters concerning the European Union.' This wording makes it clear that the German Länder do not participate in the Federation's legislation or administration directly but are, as a rule (exception e.g. Article $138 \mathrm{BL}$ ), mediated by the Bundesrat. This is confirmed by Article 23 para. 2 sentence $1 \mathrm{BL}$ with regard to matters concerning the European Union.

As a 'legislative body' the Bundesrat's task is to take part in the Federation's legislation. As already mentioned above (2.), in that regard the Basic Law (Article 77) provides for two kinds of bills: (a) bills that need the Bundesrat's consent in order to become law (veto option); (b) all other bills against which the Bundesrat can raise objections (suspensive veto that can be outvoted by the Bundestag). The requirement of the Bundesrat to give its consent to a bill must explicitly be provided for in the Basic Law (numerus clausus). The original idea of the authors of the Basic Law was to construe the 'consent option' as the exception while the 'objection option' was to be the rule (Oeter 1998: 159). Surprisingly, however, as of the early years the number of bills that required the Bundesrat's consent, exceeded the number of bills that could be objected to. One important reason for this situation was the then Article $84 \mathrm{BL}$ which required the consent of the Bundesrat for federal bills which provided for the establishment of administrative authorities or which regulated administrative procedures (Oeter 1998: 159).

The description of the legislative task of the Bundesrat would be incomplete without mentioning its right to legislative initiative as provided for in Article 76 BL. Importantly, the right of the Bundesrat to legislative initiative is not substantially limited; in particular it is not restricted to Länder interests (Reuter 2007, Artikel 50 GG mn. 127). The number of legislative initiatives of the Bundesrat, however, is comparatively small (Reuter 2007, Artikel 50 GG mn. 130).

Besides legislation the Bundesrat fulfills many other tasks (for an overview cf. Schmidt 2012, p. 674 et seq.) among which its participation in the administration of the Federation is a particularly important role (Robbers 2018, Artikel 50 GG mn. 29). Furthermore, the Bundesrat is involved in matters concerning the European Union (cf. Article 23 BL). 


\subsection{Composition of the Bundesrat}

The Bundesrat has no legislative period: instead, like the Council of the EU or the European Council, it is an 'eternal' institution (Kotzur 2006: 273 et seq.). Pursuant to Article 51 para. $1 \mathrm{BL}$ the Bundesrat 'shall consist of members of the Land governments, which appoint and recall them'. The composition of the Bundesrat distinguishes it from 'real' second chambers. This is an (almost, cf. Russell 2001: 108 et seq.) unique feature of the German federal system. In fact, the 'real members' of the Bundesrat are not its determined members pursuant to Article 51 BL but the Länder themselves (cf. Schöbener 2010, Article $51 \mathrm{BL}, \mathrm{mn}$. 14). Thus, the Länder, or rather the Land governments, have the right - and duty - to instruct their members of the Bundesrat. This does not follow from the wording of the Basic Law but from an interpretation of its provisions. Furthermore, some Land Constitutions confirm that interpretation (cf. Leunig 2009a: 98).

An asymmetric element of German federalism is the unequal (over- or under-) representation of the Länder in the Bundesrat. Pursuant to Article 51 para. 2 BL each Land shall have at least three votes; Länder with more than two million inhabitants shall have four, Länder with more than six million inhabitants five, and Länder with more than seven million inhabitants six votes. This provision amounts to the number of votes of each Land as demonstrated in the table above (2.). In European Union law the principle described here is called 'degressive proportionality' (cf. Article 14 para. 2 TEU). It provides for a compromise between federative and democratic representation (Eith and Siewert 2010: 105). Thus, an exception to the general principle of equality of the Länder applies.

The governmental (or executive) composition of the Bundesrat continues through to its committees. Article 52 para. $4 \mathrm{BL}$ assigns a large margin of discretion to the Länder in that it entitles the Länder to send not only other members but also 'representatives' (Beauftragte) of the Land governments into the committees of the Bundesrat. The term 'representatives' is not defined and implies no particular personal requirements (Reuter 2007, Artikel 52 GG mn. 56). In practice, work in the committees of the Bundesrat is dominated by the Land bureaucracy and its (executive) expertise (cf. Kluth 2011: 214; Leunig 2009a: 97 et seq.). The primary role of the Land bureaucracy in the decision-making process of the Bundesrat is evidenced by the huge number of meetings of the committees and subcommittees of the Bundesrat compared to its plenary sessions (Sturm 2009: 147). Unlike in the plenum of the Bundesrat, in its committees each Land has one vote (cf. $\int 42$ para. 2 of the Bundesrat's Rules 
of Procedure). This may lead to committee decisions which do not anticipate the plenum's decision (Leunig 2009a: 99).

\subsection{Voting in the Bundesrat}

Pursuant to Article 52 para. 3 sentence $1 \mathrm{BL}$ decisions of the Bundesrat shall require at least a majority of its votes (35 of 69 ). The members of each Land must cast the Land votes as a unit (Article 51 para. 3 sentence $2 \mathrm{BL}$ ). It suffices that one Bundesrat member of a Land is present in the meeting. This member is entitled, and obliged, to cast all votes of the Land. This provision proves to be problematic in coalition governments which may have split opinions on an issue which is on the Bundesrat's agenda. In fact, today all Land governments are coalition governments except Bavaria (cf. the table above, 2.). Usually, coalition agreements provide for the possibility of diverging opinions within the government in that the Bundesrat members have to abstain from voting if no prior agreement has been reached (Schmidt 2012: 673; cf., e.g., the coalition agreement between the LINKE, SPD and Bündnis 90/Die Grünen of December 4, 2014, p. 95). The requirement to cast all votes as a unit was infringed in 2002 when the Land Brandenburg, when voting on the Immigration Act (Zuwanderungsgesetz) did not cast its votes uniformly but openly differently. After reprehending the Land, the then President of the Bundesrat Klaus Wowereit asked the Minister President of Brandenburg, Manfred Stolpe, to clarify the Land's position, which he did ('yes'). The Federal Constitutional Court subsequently declared the Immigration Act void (BVerfGE 106, 310). It stated that the President of the Bundesrat was not permitted to count the casting of the votes for the Land Brandenburg by the Minister President as an agreement of the Land to the Immigration Act. The Minister President, the Court said, cannot be regarded as the holder of the block votes if a Bundesrat member of the Land in question contradicts.

\subsection{Role and constitutional status of the Conciliation Committee} (Vermittlungsausschuss)

It is clear that the Basic Law does not provide for a classic two-chamber parliament; however, the Conciliation Committee can be regarded as a sort of 'nucleus' of a 'German Diet' (cf. Kotzur 2006: 267 and 281: '... the 'Vermittlungsausschuss' can become the true legislator'). The Conciliation Committee (cf. Schmedes 2017: 279 et seq.) is neither an 
institution of the Bundestag, nor of the Bundesrat, but a joint institution of both legislative bodies, a 'sui generis' institution (Kokott 2014, Artikel 77 GG mn. 91; Schöbener 2010, Artikel 50 GG mn. 21). According to its Rules of Procedure ( $(1)$ the Committee is composed in parity: It consists of 16 members of the Bundestag and 16 members of the Bundesrat. The Conciliation Committee's task is to jointly consider a bill (cf. Article 77 para. 2 sentence $1 \mathrm{BL})$. This is particularly important when the Bundesrat's consent is required. In that case the Bundesrat, the Bundestag and the Federal Government are entitled to convene the Committee. When the Bundesrat can only raise objections to a bill, solely the Bundesrat can convene the Committee. To object to a bill requires the prior convention the Committee (Eith and Siewert 2010: 108).

\section{The Bundesrat as a 'second chamber' of the German parliament}

As already mentioned (cf. above, 3.5.), it is obvious that the Basic Law doesn't provide for a classic two-chamber parliament. No mention is made in the Basic Law of a 'parliament' that incorporates the Bundestag and the Bundesrat as two chambers or houses. Rather, the Basic Law establishes two legislative bodies (cf. Articles 55 para. 1, 59 para. 2, 122 para $1 \mathrm{BL}$ ) of which the Bundestag is the main legislator while the Bundesrat's involvement in legislation is reduced (cf. above, 3.2.). Formally, thus, the Bundesrat is not a classic second chamber.

This was confirmed by the Federal Constitutional Court which argued in its decision of June 25, 1974 (BVerfGE 37, 363/380) that 'pursuant to the Basic Law, the Bundesrat is not a second chamber of a uniform legislative organ that participates in the legislative process on an equal footing with the first chamber' (translation from German by the author). What the Court, however, did not do, was to rule out categorically the possibility of classifying the Bundesrat as a second chamber. With its statement the Federal Constitutional Court allowed for the fact that the 'World of Second Chambers' (cf. Luther, Passaglia and Tarchi 2006) is colourful and highly differentiated (Leunig 2009b, p. 16). Only a broad definition such as that given by Thomas Groß (Groß 2003: 31) is adequate to grasp the manifold manifestations of second chambers in the world. Thus, irrespective of its atypical composition, its reduced participation in federal law-making and other features, the Bundesrat must functionally be regarded as a second chamber (Leunig 2009: 16). 
The constitutional role of the Bundesrat, expressed in its functions, tasks and rights, is not dependent on it being classified as a second chamber. In that regard, the secondchamber question is purely terminological in nature (Schöbener 2010, Artikel 50 GG mn. 19) and without legal significance. However, from the perspective of EU law the classification of the Bundesrat as a second chamber is legally important in order to justify the inclusion of the Bundesrat in the task assigned to the national parliaments of 'seeing to it that the principle of subsidiarity is respected in accordance with the procedures provided for in the Protocol on the application of the principles of subsidiarity and proportionality' (Article 12 lit. b) TEU). For this purpose, the Bundesrat must be, and is in fact, viewed as a 'chamber of a national Parliament' in the meaning of Protocol No. 2 on the application of the principle of subsidiarity and proportionality annexed to the Lisbon Treaty.

To conclude, German federalism is constituted as a bicameral system with two legislative bodies which are functionally the two chambers of the German parliament.

\section{The German Bundesrat and 'executive federalism'}

The German constitutional system if often referred to as 'executive federalism'; it even seems that German federalism can be regarded as an embodiment of that concept, and the Bundesrat plays an important role in that characterisation. Before dealing with the concept of 'executive federalism' it must be distinguished from other types of federalism. Dann (2004: 40 et seq.) has identified three structural types of federalism: (1) separative federalism (Trennföderalismus; example: USA); direct democratic interlaced federalism (direktdemokratischer Verflechtungsföderalismus; example: Switzerland); executive federalism (Exekutivföderalismus; example: Germany).

It goes without saying that the three types mentioned above represent very broad concepts. As Federico Fabbrini has stated, the notion 'executive federalism' is multifaceted (Fabbrini 2015: 289). Not surprisingly, the definitions proposed by scholars from several disciplines differ considerably in detail but have a common core in that they stress the modes of execution of laws or the dominant role of the executive branch. All in all, it seems that scholars use their own definition tailored for their particular purposes. This is reflected in the following definitions. 
Robert Schütze calls 'executive federalism' a decentralised model which 'entrusts the execution of federal law principally to the Member States' (Schütze 2010: 1389). This model, as Schütze correctly says, characterises German federalism. Federico Fabbrini finds that Schütze's definition is specific (Fabbrini 2015: 289 et seq.). Referring to Ronald Watts, he applies a 'more general' definition that points to the modes of intergovernmental negotiations which are dominated by the executives of the governments of the federal tiers. A similar definition is applied by Philipp Dann (2004: 41). Hans-Jürgen Papier stresses the process of strengthening of the Land governments at the cost of the Land parliaments: The former receive participatory rights at the federal level (within the Bundesrat) in exchange for a loss of legislative competences of the Länder (Papier 2012: 370). He also calls this compensatory mechanism 'Beteiligungsförderalismus' (participative federalism). Jacques Ziller submits an approach, that, he says, is more appropriate for a legal analysis then the usual political science perspective' (Ziller 2010: 261). He calls 'executive federalism' the 'organization of the executive function amongst levels of government'. Ines Härtel, to mention a last example, conceives 'executive federalism' as bargaining of the executive in Bund-Länder or Länder commissions which, even though regularly not legally binding, are de facto binding for the Land parliaments (Härtel 2012: 439).

The Bundesrat's significance within the definitions listed above differs. Some definitions primarily refer to the distribution of powers between the Federation (legislation) and the Länder (execution) and, thus, affect the Bundesrat only indirectly. Others stress the need for intergovernmental coordination and bargaining between the federal tiers. The narrowest definition refers to the existence of a Council that consists of members of the component units and takes part in federal legislation (Dann 2004: 41) which is, of course, modelled on the German system. However, it is not necessary to apply the narrowest possible definition of 'executive federalism' in order to include the Bundesrat. Rather, most definitions mentioned above describe features which refer, directly or indirectly, to the German Bundesrat. 


\section{Implications of German federalism reform for the German Bundesrat}

Over the course of time, German federalism has repeatedly been subject to reform efforts (cf. Gunlicks 2012: 115 et seq.). Inevitably, those reforms did not leave the Bundesrat unaffected, sometimes only by reflection, sometimes by intention. Major criticism was raised concerning the Bundesrat's power to veto the Bundestag's legislative decisions. Before the federalism reform of 2006 more than $60 \%$ of federal bills were estimated to have required the Bundesrat's consent (Sturm 2009: 145). In recent times the number of legislative cases that have required the consent of the Bundesrat have reduced significantly (cf. Benz, Detemple and Hein 2013: 155; Sturm 2012: 737). From then on, for example, the Federation could regulate the establishment of Land authorities and their administrative procedure without the consent of the Bundesrat (cf. new Article $84 \mathrm{BL}$ ). In return, the Länder were assigned the right to deviate from federal legislation enacted in that field (cf. Niedobitek 2013: no. 9 et seq.). The third and last part of the recent federalism reform, which essentially concerned the introduction of a new model of fiscal equalisation, (Amendment of the Basic Law of July 13, 2017, BGBl. 2017 I 2347) reversed the trend, increasing requirements for the Bundesrat's consent and the joint-decision mode (Gamper 2017: 121 and 123).

There is no lack of reform options and proposals for the German Bundesrat as such, however improbable they may be. A few examples may suffice. First, it has been proposed to replace the Bundesrat by a 'Senate' whose members are elected by the Land parliaments or directly by the Land people (Papier 2012: 381 et seq.). This proposal refers to the discussions that took place when the Basic Law was founded (cf. Eith and Siewert 2010: 101). Second, a change of the voting requirements has been proposed, from absolute majority voting to a relative majority (Eith and Siewert 2010: 118). Third, a proposal to allow the Länder to no longer cast their votes en bloc but in accordance with their political affiliation has been made (cf. Eith and Siewert 2010: 118 et seq.). This could avoid abstentions, as provided for in coalition agreements in the case of split opinions with the government. Fourth, territorial reform of the Länder is being discussed (cf. Papier 2012: 379 et seq.). The issue is important for the composition of the Bundesrat since it could justify an equal distribution of the votes of the Bundesrat. However, in the light of previous federalism 
reforms, it is doubtful whether fundamental changes of the constitutional design of the Bundesrat will happen in the near future.

\section{Summary}

Germany is a federal state with two state tiers: the Bund (federation) and the Länder (component units). As a rule, the exercise of state powers and the discharge of state functions is a matter for the Länder (Article 30 Basic Law). A closer look at the German Basic Law reveals, however, that the Bund dominates legislation while the Länder's domain is execution. This is a first justification to call German federalism 'executive federalism'. Legislation of the Bund is not protected from Länder influence. This influence is, however, only indirect. The Länder are represented (mediated) in the Bundesrat which is, legally speaking, a federal organ, not a Länder organ. The Bundesrat consists of appointed members of the Land governments who are (to be) instructed by their respective Land government. This is a second, and the most convincing, justification to speak of 'executive federalism' in the German context. Thus, the existence of the Bundesrat and its constitutional design justify German federalism's appellation of 'executive federalism'.

The Bundesrat takes part in the legislation and administration of the Bund. As regards legislation, the powers of the Bundesrat are strong when its consent is required; against other laws the Bundesrat can raise objections (which can be outvoted by the Bundestag). The number of laws requiring the consent of the Bundesrat was reduced by Federalism Reform I (2006) in order to unbundle the competence spheres of the Bund and the Länder.

The legislative function of the Bundesrat makes it a 'legislative body' (Article 55; cf. also 59 para. 2 Basic Law). However, the question of whether to call the Bundesrat a 'second chamber' of a German parliament is disputed; formally, this is not the case but functionally the Bundesrat must be regarded as a 'second chamber'. However, to call the Bundesrat a 'second chamber' or not is not significant for the legal scope of its constitutional role. At the EU level, though, it is important for the Bundesrat to be regarded as a second chamber.

The constitutional design of the Bundesrat has necessarily led to intertwined (joint) decision-making (according to Fritz W. Scharpf) which has frequently drawn criticism, and reform efforts are aimed at unbundling legislative competences of the two federal tiers as well as at reforming the Bundesrat itself. The latter proposals include the introduction of a 
Senate model of territorial representation, new voting mechanisms in the Bundesrat or the abolishment of the requirement to cast the votes of each Land as a unit. In the light of the long tradition of the Bundesrat model and its close relationship with German federalism as such, however, it is doubtful whether fundamental changes of the constitutional design of the Bundesrat will occur.

\footnotetext{
* Director of the Institut für Europäische Studien, Jean Monnet Professur für Europäische Integration, Philosophische Fakultät, TU Chemnitz (Germany).

${ }^{\mathrm{I}} \mathrm{BVerfGE}=$ Decisions of the Federal Constitutional Court.

II Cf. the coalition agreement on the federal government's website: https://www.bundesregierung.de/Content/DE/ Anlagen/2018/03/2018-03-14-koalitionsvertrag.html.

III Cf. https://www.bundeswahlleiter.de/service/wahltermine.html.
}

\section{References}

- $\quad$ Basic Law, English version of the Grundgesetz provided by Christian Tomuschat, David P. Currie and Donald P. Kommers (https://www.gesetze-im-internet.de/englisch gg/index.html).

- Benz Arthur, 2015, 'Föderalismus und Demokratie - Anmerkungen zu einem Spannungsverhältnis', in Jabrbuch des Föderalismus 2015, Nomos, Baden-Baden, 192-201.

- Benz Arthu, Detemple Jessica and Heinz Dominic, 2013, 'Varianten und Dynamiken der Politikverflechtung', in Jabrbuch des Föderalismus 2013, Nomos, Baden-Baden, 155-165.

- Blanke Hermann-Josef, 2016, 'Artikel 300 AEUV', in Grabitz Eberhard, Hilf Meinhard and Nettesheim Martin (eds), Das Recht der Europäischen Union, looseleaf, Verlag C. H. Beck, München.

- Burgess Michael, 2008, 'Das Paradox der Diversität: Asymmetrischer Föderalismus aus vergleichender Perspektive', in Jabrbuch des Föderalismus 2008, Nomos, Baden-Baden, 103-116.

- Coalition agreement between the LINKE, SPD and Bündnis 90/Die Grünen of December 4, 2014, https://www.die-linke-thueringen.de/fileadmin/LV Thueringen/dokumente/r2g-koalitionsvertrag-final.pdf (accessed on April 30, 2018).

- Dann Philipp, 2004, Parlamente im Exekutivföderalismus, Springer, Berlin et al.

- Eith Ulrich and Siewert Markus B., 2010, 'Das "unechte" Unikat: der Deutsche Bundesrat', in Riescher Gisela, Ruß Sabine and Haas Christoph M. (eds), Zweite Kammern, 2nd ed., Oldenbourg Wissenschaftsverlag, München.

- $\quad$ Fabbrini, Federico, 2015, 'From Executive Federalism to Executive Government: Current Problems and Future Prospects in the Governance of EMU', in Fabbrini Federico, Hirsch Ballin Ernst and Somsen Han (eds), What Form of Government for the European Union and the Eurozone?, Hart Publishing, Oxford, 289-306.

- Groß Thomas, 2003, 'Zwei-Kammer-Parlamente in der Europäischen Union', Zä̈RV, no. 63: 29-57.

- Gunlicks Arthur B., 2003, The Länder and German federalism, Manchester University Press, Manchester and New York.

- Gunlicks Arthur B., 2012, 'Reforming German federalism', in Appleby Gabrielle, Aroney Nicholas and John Thomas (eds), The Future of Australian Federalism, Cambridge University Press, Cambridge, 115-140.

- Härtel Ines, 2012, 'Der staatszentrierte Föderalismus zwischen Ewigkeitsgarantie und Divided Government. Genese, Ausprägung und Problemhorizonte des Bundesstaatsprinzips', in Härtel Ines (ed), Handbuch Föderalismus, Band I: Grundlagen des Föderalismus und der deutsche Bundesstaat, Springer, Heidelberg et al., 387-476.

- $\quad$ Kluth Winfried, 2011, 'Gesetzgebung im Spannungsfeld von Parlamentarismus und Föderalismus Reformperspektiven für das Vermittlungsverfahren', in Baumeister Peter, Roth Wolfgang and Ruthig Josef (eds), Staat, Verwaltung und Rechtsschutz - Festschrift für Wolf-Rüdiger Schenke zum 70. Geburtstag, Duncker \& Humblot, Berlin, 213-232. 
- $\quad$ Kokott Juliane, 2014, 'Artikel 77 Grundgesetz', in Kahl Wolfgang, Waldhoff Christian and Walter Christian (eds), Bonner Kommentar zum Grundgesetz, loose-leaf edition, Heidelberg.

- Kotzur Markus, 2006, 'Federalism and Bicameralism - The German "Bundesrat" (Federal Council) as an Atypical Model', in Luther Jörg, Passaglia Paolo and Tarchi Rolando (eds), A World of Second Chambers. Handbook for Constitutional Studies on Bicameralism, Giuffrè Editore, Milano, 257-290.

- Leunig Sven, 2009a, 'Der deutsche Bundesrat: Einzigartig, einflussreich, aber nicht unumstritten', in Leunig Sven (ed), Handbuch Föderale Zweite Kammern, Verlag Barbara Budrich, Opladen \& Farmington Hills, 95-113.

- Leunig Sven, 2009b, 'Einführung', in Leunig Sven (ed), Handbuch Föderale Zweite Kammern, Verlag Barbara Budrich, Opladen \& Farmington Hills, 15-18.

- $\quad$ Luther Jörg, Passaglia Paolo and Tarchi Rolando (eds), 2006, A World of Second Chambers. Handbook for Constitutional Studies on Bicameralism, Giuffrè Editore, Milano.

- $\quad$ Niedobitek, Matthias, 2001, Das Recht der grenzüberschreitenden Verträge - Bund, Länder und Gemeinden als Träger grenzüberschreitender Zusammenarbeit, Mohr Siebeck, Tübingen.

- $\quad$ Niedobitek Matthias, 2013, 'Germany - Sub-national Constitutional Law' (update August 2012), in International Encyclopaedia of Laws (general ed.: Roger Blanpain), Constitutional Law - Sub-national Constitutional Law (eds: André Alen and David Haljan), Wolters Kluwer, Alphen aan den Rijn.

- Oeter Stefan, 1998, Integration und Subsidiarität im deutschen Bundesstaatsrecht, Mohr Siebeck, Tübingen.

- Papier Hans-Jürgen, 2012, 'Steuerungsprobleme und die Modernisierung bundesstaatlicher Ordnung', in Härtel Ines (ed), Handbuch Föderalismus, Band I: Grundlagen des Föderalismus und der deutsche Bundesstaat, Springer, Heidelberg et al., 361-385.

- $\quad$ Reuter Konrad, 2007, Praxishandbuch Bundesrat, 2nd ed., C. F. Müller Verlag, Heidelberg.

- Risse Horst, 2005, 'The Bundesrat in the federal legislative process', in Robbers Gerhard (ed), Reforming Federalism - Foreign Experiences for a Reform in Germany, Verlag Peter Lang, Frankfurt/Main, 11-16.

- $\quad$ Robbers Gerhard, 2018, 'Artikel 50 Grundgesetz', in Sachs Michael (ed), Grundgesetz - Kommentar, 8 ${ }^{\text {th }}$ ed., Verlag C. H. Beck, München.

- $\quad$ Russell Meg, 2001, 'The Territorial Role of Second Chambers', Journal of Legislative Studies, VII(1): 105118.

- Schmedes Hans-Jörg, 2017, 'Zwischen Konkurrenz und Konkordanz: Der Vermittlungsausschuss von Bundestag und Bundesrat in Zeiten gegenläufiger Mehrheiten', in Jahrbuch des Föderalismus 2017, Nomos, Baden-Baden, 279-294.

- Schmidt Thorsten Ingo, 2012, 'Der Bundesrat. Geschichte, Struktur, Funktion', in Härtel Ines (ed), Handbuch Föderalismus, Band I: Grundlagen des Föderalismus und der deutsche Bundesstaat, Springer, Heidelberg et al., 651-689.

- $\quad$ Schöbener Burkhard, 2010, 'Artikel 50-53 Grundgesetz ' (Grundgesetz), in Kahl Wolfgang, Waldhoff Christian and Walter Christian (eds), Bonner Kommentar zum Grundgesetz, loose-leaf edition, Heidelberg.

- Schütze Robert, 2010, 'From Rome to Lisbon: “Executive Federalism” in the (new) European Union', in Common Market Law Review, XLVII(5): 1385-1427.

- $\quad$ Sturm Roland, 2008, 'Von der Symmetrie zur Asymmetrie - Deutschlands neuer Föderalismus', in Jahrbuch des Föderalismus 2007, 27-41.

- Sturm Roland, 2009, 'Der Bundesrat im Grundgesetz: falsch konstruiert oder falsch verstanden?', in Jabrbuch des Föderalismus 2009, Nomos, Baden-Baden, 137-148.

- Sturm Roland, 2012, 'Zweite Kammern in Deutschland und Europa: Repräsentation, Funktion, Bedeutung', in Ines Härtel (ed), Handbuch Föderalismus, Band I: Grundlagen des Föderalismus und der deutsche Bundesstaat, Springer, Heidelberg et al., 723-742.

- Sturm Roland and Winkelman Thorsten, 2014, 'Symmetrie und Asymmetrie im deutschen Föderalismus - übliche Missverständnisse und übersehene Folgen', in Jabrbuch des Föderalismus 2014, Nomos, Baden-Baden, 46-62.

- Ziller, Jacques, 2010, 'Multilevel Governance and Executive Federalism: Comparing Germany and the European Union', in Birkinshaw Patrick and Varney Mike (eds), The European Union Legal Order after Lisbon, Wolters Kluwer, Austin et al., 257-275. 